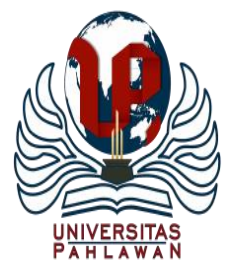

Edukatif : Jurnal Ilmu Pendidikan Volume 3 Nomor 4 Tahun 2021 Halm 1298 - 1308

EDUKATIF: JURNAL ILMU PENDIDIKAN

Research \& Learning in Education

https:/ledukatif.org/index.php/edukatif/index

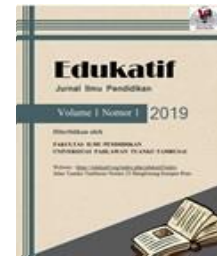

\title{
Pengembagan E-Modul Berbasis Digital Flipbook Untuk Mempermudah Pembelajaran Jarak Jauh Di SMA
}

\author{
Kalimatus Sa'diyah ${ }^{凶}$ \\ Universitas Negeri Surabaya, Indonesia \\ E-mail : kalimatus17080554081@mhs.unesa.ac.id
}

\begin{abstract}
Abstrak
Berdasarkan observasi yang dilakukan bahwa sumber belajar di SMA Negeri 14 Surabaya masih buku keluaran penerbit. Buku yang digunakan hanya berisi materi teks bacaan tidak ada gambar pendukung materi serta warna dan background gambar yang terlihat monoton. Disamping itu rendahnya minat belajar peserta didik juga menjadi masalah dalam proses pembelajaran, banyak peserta didik yang belum mengetahui tujuan pembelajaran yang harus mereka capai. Tujuan penelitian pengembangan ini yaitu mengetahui kelayakan penggunaan secara teoritis dan empiris serta mengetahui kepraktisan penggunaan E-modul berbasis digital flipbook. Jenis penelitian yang digunakan adalah penelitian pengembangan model 4-D dengan empat tahap prosedur pengembangan: (1)pendefinisian, (2)perencanaan, (3)pengembangan. Teknik analisis data dilakukan secara deskriptif kuantitatif meliputi kelayakan teoritis berupa hasil validasi, kelayakan empiris berupa hasil uji keterbacaan dan angket peserta didik yang diambil dari 20 peserta didik Kelas X IPS SMA Negeri 14 Surabaya. Hasil penelitian menunjukkan bahwa E-modul berbasis digital flipbook memperoleh nilai rata-rata 0,91 dari hasil validasi menunjukkan bahwa E-modul berbasis digital flipbook termasuk dalam kategori valid dan layak secara teoritis. Uji keterbacaan berada dilevel 10 artinya sesuai dengan kelas 10 serta hasil rata-rata dari respon peserta didik sebesar $82 \%$ pada pernyataan positif dan $39 \%$ pada pernyataan negatif termasuk kategori sangat layak secara empiris.
\end{abstract}

Kata Kunci: E-modul, Flipbook, Terbentukya keseimbangan pasar dan struktur pasar

\begin{abstract}
Based on observations done, books used only contain reading text material, monotonous and unattractive. The low interest in learning of students is also a problem in the learning process. The purpose of this study is to determine the feasibility of using theoretically and empirically and to know the practicality of using the digital flipbook-based E-module. This type of research is a 4-D model development research with four stages of development procedures. The data analysis technique was carried out in a descriptive quantitative manner including theoretical feasibility in the form of validation results, empirical feasibility in the form of legibility test results, and student questionnaires. The results showed that the digital flipbook-based E-module obtained an average value of 0.91 from the validation results indicating that the digital flipbook-based E-module was categorized as valid and theoretically feasible. The readability test is at level 10, which means that it is in accordance with class 10 and the average result of students' responses is $82 \%$ for positive statements and 39\% for negative statements, including the empirically very feasible category.
\end{abstract}

Keywords: E-modul, Flipbook, formation of market equilibrium and market structure

Copyright (c) 2021 Kalimatus Sa'diyah

Corresponding author:

Email : kalimatus.17080554081@mhs.unesa.ac.id

DOI : https://doi.org/10.31004/edukatif.v3i4.561

ISSN 2656-8063 (Media Cetak)

ISSN 2656-8071 (Media Online)

Edukatif : Jurnal Ilmu Pendidikan Vol 3 No 4 Tahun 2021 p-ISSN 2656-8063 e-ISSN 2656-8071 
1299 Pengembagan E-Modul Berbasis Digital Flipbook Untuk Mempermudah Pembelajaran Jarak Jauh Di SMA - Kalimatus Sa'diyah

DOI: https://doi.org/10.31004/edukatif.v3i4.561

\section{PENDAHULUAN}

Hasil penelitian yang dilakukan oleh Program For Internasional Student Assessment (PISA) pada tahun 2018 menyatakan bahwa tingkat kemampuan membaca pelajar di Indonesia berada dipringkat 6 dari bawah yaitu peringkat 74 dari 80 negara di dunia dengan rata-rata skor 371 (OECD, 2019). Dalam hal ini Indonesia masih sangat rendah dalam hal membaca. Beberapa penemuan untuk meningkatkan minat baca peserta didik yang dilakukan baik orang tua maupun guru yaitu membiasakan peserta didik membaca dengan jenis dan format buku yang beragam (Balitbang, 2019). Kebutuhan inovasi dalam pembelajaran mutlak diperlukan untuk menghadapi era kemajuan digital atau bisa disebut dengan revolusi industry 4.0 (Amanullah, 2020). Pembelajaran digital bertujuan untuk menyuguhkan situasi dan suasana baru dalam proses pembelajaran baik bagi peserta didik maupun guru, karena pembelajaran konvensional sudah tidak sesuai dengan situasi pembelajaran pada saat ini.

Peserta didik harus mendapatkan pembelajaran sesuai dengan kebutuhan dan kompetensi yang dimilki oleh peserta didik dengan menyesuaikan metode pembelajaran sesuai dengan perkembangan jaman, kesesuaian metode pembelajaran dengan perkembangan teknologi akan menarik minat peserta didik dalam proses pembelajaran (Kemdikbud, 2020a). Pandemi covid memang membuat semua pihak merasakan kesulitan dalam semua bidang termasuk bidang pendidikan. Beberapa upaya dilakukan oleh pemerintah untuk mengatasi permasalahan dalam bidang pendidikan akibat pandemi covid salah satunya adalah pendidikan jaraj jauh. Permendikbud No. 24 Tahun 2012 Pasal 1 menjelaskan pendidikan jarak jauh yang dilanjutnya disebut PJJ adalah pendidikan yang peserta didiknya terpisah dari pendidik dan pembelajarannya menggunakan berbagai sumber belajar melalui teknologi informasi, komunikasi dan media lainnya.

Pada saat pendidikan jarak jauh banyak yang masih harus disesuaikan dari metode pembelajaran, media pembelajaran serta bahan ajar yang digunakan. Dalam proses pembelajaran, buku atau modul menjadi salah satu sumber informasi yang digunakan peserta didik untuk meningkatkan pengetahuan dan motivasi belajar. Pengembangan buku maupun modul dalam format elektronik atau disebut dengan e-book/e-modul yang pada saat ini digunakan sebagai pengganti buku secara konvensional tanpa mengurangi peranannya sebagai sumber informasi (Hartanti, 2013). Salah satu penggunaan perangkat lunak untuk membuat E-modul yang diharapkan dapat memberikan daya tarik tersendiri adalah flipbook. Flipbook merupakan software yang memiliki fungsi editing yang digunakan untuk menambah hyperlink, gambar, vidio dan suara sebagai pendukung materi dan penambahan objek multimedia pada halaman yang bisa dibolak balikan seperti buku asli (Ilham, M., 2014).

Flipbook bertujuan untuk membantu peserta didik dalam pemahaman materi, meningkatkan hasil belajar peserta didik, meningkatkan keterampilan berpikir kreatif serta dapat meningkatkan motivasi belajar peserta didik (Hayati, 2015). Sehingga penggunaan E-modul berbasis digital flipbook menjadi solusi cerdas menghadirkan suasana belajar yang menarik, interaktif dan menunjang pemahaman peserta didik secara materi. E-modul berbasis digital flipbook pada prinsipnya serupa dengan bahan ajar manual (Yulaika et al., 2020). Pada E-modul berbasis digital flipbook menjabarkan Kompetensi Dasar (KD), Indikator (KI), materi, penugasan dan latihan soal yang dikemas lebih powerfull dalam bentuk elektronik berukuran A4 bentuk portrait yang di dalamnya berisi gambar, hyperlink dan suara sebagai penunjang materi yang bisa dipublikasi dalam bentuk SWF HTML, PDF dipublikasikan melalui webside, E-mail, Whatsapp dll. salah satu materi yang cocok digunakan dalam E-modul berbasis digital flipbook yaitu terbentuknya keseimbangan pasar dan struktur pasar dalam perekonomian yang mencakup permintaan, penawaran, keseimbangan harga pasar dan pasar.

Berdasarkan observasi yang dilakukan di SMA Negeri 14 Surabaya bahwa sumber belajar yang digunakan masih berupa buku keluaran penerbit. Buku paket yang digunakan berisi materi pembelajaran yang hanya berisi teks bacaan, warna-warna isi buku monoton dan kurangnya gambar ilustrasi sehingga kurang menarik minat peserta didik untuk membaca dan belajar. Disamping itu rendahnya minat belajar peserta didik 
menjadi masalah dalam proses pembelajaran serta banyak peserta didik yang belum mengetahui tujuan pembelajaran yang harus mereka capai. Guru mengaku membutuhkan suatu modul yang mendukung capaian kurikulum 2013 dan membantu mempermudah dalam proses pembelajaran pada saat pendidikan jarak jauh seperti pada saat ini. Begitu juga dengan peserta didik, mereka mengaku membutuhkan modul yang menarik sehingga dapat meningkatkan motivasi belajar, mempermudah memahami materi, mengurangi kejenuhan saat belajar serta mempermudah saat proses pembelajaran. Oleh karena itu peneliti tertarik untuk membuat bahan ajar berupa E-modul berbasis digital flipbook materi terbentuknya keseimbangan pasar dan struktur pasar. Diharapkan dengan pembuatan bahan ajar ini dapat meningkatkan motivasi belajar dan mengurangi kejenuhan dalam proses pembelajaran.

Berdasarkan uraian diatas perlu dilakukan penelitian tentang E-modul berbasis digital flipbook pada materi terbentuknya keseimbangan pasar dan struktur pasar dalam perekonomian kelas X IPS SMAN 14 Surabaya dengan tujuan untuk mengetahui kelayakan teoritis dan empris serta kepraktisan penggunaannya. Pada penelitian ini E-modul berbasis digital flipbook didesain semenarik mungkin untuk meningkatkan motivasi dan hasil belajar peserta didik serta untuk mempermudah proses guru ataupun peserta didik saat proses pembelajaran jarak jauh. Sedangkan pada penelitian pada penelitian terdahulu E-modul berbasis digital flipbook digunakan untuk meningkatkan hasil belajar peserta didik saja. Dari penelitian (Yulaika et al., 2020) menjelaskan bahwa penelitian ini bertujuan untuk mengembangkan bahan ajar eletronik dengan menggunakan media flipbook untuk meningkatkan capaian hasil belajar peserta didik serta bahan ajar berbasis flipbook yang dikembangkan layak diterapkan dan eketif dalam meningkatkan hasil belajar. Namun pada saat pandemi seperti ini peserta didik mengalami kesulitan saat proses pembelajaran, oleh karena itu harus ada inovasi baru yang bisa menjadi solusi untuk mempermudah proses pembelajaran peserta didik saat pembelajaran jarak jauh dan dapat meningkatkan motivasi serta hasil belajar peserta didik.

\section{METODE PENELITIAN}

Pada penelitian pengembangan bahan ajar berupa E-modul berbasis digital flipbook menggunakan model penelitian 4D yang dikembangkan oleh Thiagarajan (Sutarti, 2017). Prosedur pengembangan yang digunakan meliputi empat tahap : (1) pendefinisian (define) menghasilkan analisis kurikulum yang meliputi kompetensi inti (KI), kompetensi dasar (KD) serta indikator materi terbentuknya keseimbangan pasar dan struktur pasar, analisis peserta didik yang bertujuan sebagai acuan menyusun media pembelajaran, analisis konsep mengasilkan peta konsep yang menggambarkan poin-poin materi, analisis tugas dilakukan untuk mengetahui keterampilan kemampuan peserta didik, serta perumusan tujuan pembelajaran, (2) perencanaan (design) merupakan rencana awal desain media, (3) pengembangan (develop) pada tahap ini meliputi validasi yang dilakukan oleh validator, revisi produk serta uji coba produk yang akan dilakukan oleh 20 peserta didik kelas X IPS SMAN 14 Surabaya dan (4) penyebaran (dessiminate). Namun penelitian E-modul berbasis digital flipbook ini hanya sampai pada tahap pengembangan. 
1301 Pengembagan E-Modul Berbasis Digital Flipbook Untuk Mempermudah Pembelajaran Jarak Jauh Di SMA - Kalimatus Sa'diyah

DOI: https://doi.org/10.31004/edukatif.v3i4.561

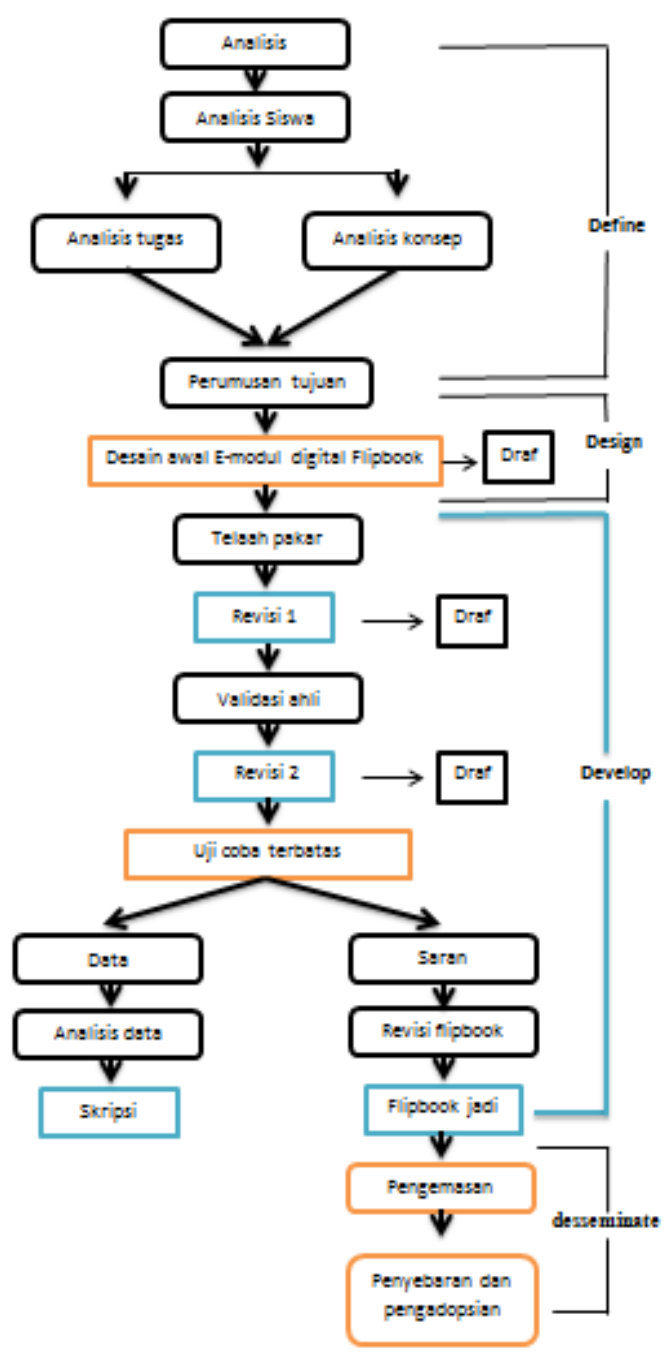

Gambar 1. Prosedur pengembangan E-modul berbasis digital flipbook model 4D

Teknik pengumpulan data dalam penelitian pengembangan ini terdiri dari kelayakan teoritis yang meliputi hasil validasi oleh validator dan kelayakan empiris yang terdiri dari uji keterbacaan dan analisis angket peserta didik.selanjutnya hasil data yang sudah diperoleh dianalisis secara deskriptif kuantitatif, berikut analisis data dalam penelitian pengembangan ini:

1. Hasil validasi E-modul berbasis digital flipbook dinyatakan valid jika nilai validasi $>0,8$. Hasil validasi dapat dihitung menggunakan rumus :

$$
V=\frac{\Sigma s}{n(c-1)}
$$

Analisis E-modul menggunakan skala likert yang diadaptasi dari (Ratnawati, 2016).

Tabel 1

Menunjukkan kriteria interpretasi hasil validasi

\begin{tabular}{cc}
\hline Kriteria & Nilai \\
\hline Valid & $>0,8$ \\
\hline Cukup valid & $0,4-0,8$ \\
\hline Tidak valid & $<0,4$ \\
\hline
\end{tabular}


1302 Pengembagan E-Modul Berbasis Digital Flipbook Untuk Mempermudah Pembelajaran Jarak Jauh Di SMA - Kalimatus Sa'diyah

DOI: https://doi.org/10.31004/edukatif.v3i4.561

2. Uji keterbacaan E-modul diperoleh dari hasil menghitung jumlah suku kata dari 100 kata dalam sebuah kalimat pada sampel E-modul yang dikalikan dengan 0,6. E-modul dinyatakan layak jika menunjukkan hasil di level 10, dimana pengembangan E-modul dilakukan pada kelas 10. Kemudian data dikonversikan kedalam grafik fry yang dikembangkan oleh Edward Fry (Sari, 2017).

3. Hasil analisis respon peserta didik dinyatakan layak jika diperoleh nilai $>61 \%$, dapat dihitung dengan rumus:

$$
\text { Presentase respon }=\frac{\text { jumuan gwor wesenunuan }}{\text { Jumlah ghor moksimal }} \times 10036
$$

dianalisis menggunakan skala likert yang diadaptasi dari (Riduwan, 2015).

Tabel 2

Menunjukkan kriteria interpretasi skor hasil respon peserta didik

\begin{tabular}{cl}
\hline \multicolumn{1}{c}{ Nilai } & \multicolumn{1}{c}{ Kriteria } \\
\hline $81 \%-100 \%$ & Sangat layak \\
\hline $61 \%-80 \%$ & Layak \\
\hline $41 \%-60 \%$ & Cukup layak \\
\hline $21 \%-40 \%$ & Kurang layak \\
\hline $0 \%-20 \%$ & Tidak layak \\
\hline
\end{tabular}

\section{HASIL DAN PEMBAHASAN PENELITIAN}

Penelitian pengembangan ini berupa E-modul berbasis digital flipbook materi terbentuknya harga pasar dan struktur pasar dalam perekonomian. E-modul berbasis digital flipbook merupakan buku digital yang dibuat dan digunakan dengan menggunakan aplikasi flipbook maker dengan tema warna yang telah disesuaikan dengan materi terbentuknya keseimbangan pasar dan struktur pasar dalam perekonomian yang berisi materi, gambar dan hyperlink. E-modul berbasis digital flipbook disajikan dengan desain yang menarik, setiap topik memiliki perbedaan tema warna serta terdapat gambar pendukung materi.

E-modul berbasis digital flipbook terdiri dari 3 bagian yaitu pendahuluan, isi dan penutup. Penyusunan E-modul berbasis digital flipbook disesuaikan dengan Kompetensi Inti (KI), Kompetensi Dasar (KD) dan Indikator. E-modul berbasis digital flipbook merupakan buku digital yang berukuran A4 dalam bentuk portrait yang didalamnya menyediakan materi terbentuknya harga pasar dan struktur pasar yang dikemas sedimikian rupa dan memilki efek flip (membuka atau membalik lembar demi lembar halaman buku sehingga seperti membaca buku sungguhan). E-modul berbasis digital flipbook dapat dipublikasi dalam bentuk SWF , HTML, PDF dan dipublikasikan melalui webside, e-mail, whatsapp dan media digital lainnya. Kelayakan E-modul berbasis digital flipbook diukur secara teoritis yang dilihat berdasarkan hasil validasi dan kelayakan empiris yang dilihat berdasarkan hasil uji keterbacaan dan hasil angket peserta didik.

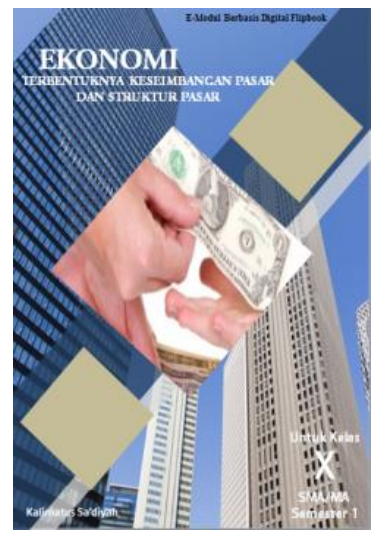

Gambar 2. Tampilan E-modul berbasis digital flipbook 
1303 Pengembagan E-Modul Berbasis Digital Flipbook Untuk Mempermudah Pembelajaran Jarak Jauh Di SMA - Kalimatus Sa'diyah

DOI: https://doi.org/10.31004/edukatif.v3i4.561

Kelayakan teoritis ditinjau berdarkan hasil validasi yang meliputi penyajian, isi materi, bahasa, kebermanfaatan, desain, tata letak, tipografi dan ilustrasi E-modul berbasis digital flipbook. Berikut hasil rekapitulasi hasil validasi E-modul berbasis digital flipbook. Berikut ini merupakan hasil validasi E-modul berbasis digital flipbook.

Tabel 3

Hasil validasi E-modul berbasis digital flipbook

\begin{tabular}{clcl}
\hline No & Aspek penilaian & $\begin{array}{c}\text { Nilai } \\
\text { rata-rata }\end{array}$ & Kategori \\
\hline \multicolumn{4}{c}{ Lembar telaah validasi materi } \\
\hline 1 & Kelayakan materi & 0,95 & Valid \\
\hline 2 & Penggunaan bahasa & 0,87 & Valid \\
\hline 3 & Kebernanfaatan & 0,83 & Valid \\
\hline \multicolumn{4}{c}{ Lembar telaah validasi media } \\
\hline 5 & Desain & 0,87 & Valid \\
\hline 6 & Tata letak & 1 & Valid \\
\hline 7 & Tipografi & 0,87 & Valid \\
\hline Rata-rata nilai keseluruhan & 0,91 & Valid \\
\hline
\end{tabular}

Sumber (Zunaidah, 2016) dengan modifikasi

Berdasarkan hasil validasi yang ditunjukkan pada Tabel 3 memperoleh nilai rata-rata keseluruhan sebesar 0,91 yang dinyatakan valid. Sesuai dengan kriteria interpretasi hasil validasi bahwa E-modul berbasis digital flipbook akan dinyatakan valid jika memperoleh nilai >0,8 dalam perhitungan skala likert (Ratnawati, 2016). Dari hasil validasi menyatakan bahwa E-modul berbasis digital flipbook sudah sesuai dengan syarat dan ketentuan penyusunan bahan ajar yang layak digunakan untuk pembelajaran. Hal ini sesuai dengan penelitian yang dilakukan (Yulaika et al., 2020) menyatakan struktur E-modul pada umumnya sama seperti bahan ajar biasa yang terdiri dari pendaluan, isi dan penutup serta dikemas praktis dan menarik. E-modul berbasis digital flipbook yang dikembangkan dinilai berdasarkan 7 aspek komponen yaitu komponen kelayakan materi, komponen penggunaan bahasa, komponen kebermanfaatan, komponen desain, komponen tata letak, komponen tipografi dan komponen ilustrasi.

Kelayakan materi E-modul berbasis digital flipbook memperoleh rata-rata 0,95 termasuk kategori valid. E-modul berbasis digital flipbook telah disesuaikan dengan Kompetensi Inti (KI), Kompetensi Dasar (KD) yang dikembangkan menjadi indikator-indikator yang disajikan secara runtut (Kemdikbud, 2020b). Pada Emodul berbasis digital flipbook materi disusun dengan jelas dan mudah dipahami oleh peserta didik, namun penggunaan E-modul berbasis digital flipbook belum sepenuhnya dimengerti oleh peserta didik. Pada komponen pengunaan bahasa memperoleh nilai rata-rata sebesar 0,87 termasuk kategori valid. E-modul berbasis digital flipbook menggunakan bahasa sesuai dengan EYD, jelas, mudah dipahami dan tidak menimbulkan multitafsir. Pendukung penyajian materi dalam bahan ajar terdiri atas istilah sesuai dengan Kamus Besar Bahasa Indonesia (KBBI) (Badanbahasa, 2021). Kategori kebermanfaatan memperoleh nilai rata-rata 0,83 dengan kategori valid. Hal ini sesuai dengan tujuan E-modul berbasis digital flipbook yaitu untuk membantu guru maupun peserta didik dalam proses pembelajaran. Dengan adanya E-modul berbasis digital flipbook peserta didik mengaku lebih mudah saat proses pembelajaran maupun pada saat belajar secara mandiri. Diperkuat oleh penelitian yang dilakukan ((Rahmawati et al., 2017) bahwa E-modul dapat membantu mempermudah proses pembelajaran baik guru maupun peserta didik. Sedangkan pada komponen 
1304 Pengembagan E-Modul Berbasis Digital Flipbook Untuk Mempermudah Pembelajaran Jarak Jauh Di SMA - Kalimatus Sa'diyah

DOI: https://doi.org/10.31004/edukatif.v3i4.561

desain, tata letak, tipografi dan ilustrasi masing-masing memperoleh nilai rata-rata sebesar $0,87,1,0,87,0,93$ semuanya termasuk kategori valid. E-modul berbasis digital flipbook didesain dengan menarik, warna yang serasi, gambar yang digunakan menggunakan gambar free lisensi yang disesuaikan dengan background pendukung flipbook tersebut. Dalam E-modul berbasis digital flipbook ada beberapa kesalahan ketik dalam penulisan. Penggunaan E-modul yang sesuai, menarik, bervariasi dan menghasilkan suasana belajar yang berbeda jika diterapkan pada peserta didik dapat meningkatkan motivasi belajar peserta didik dan mengurangi kejenuhan saat belajar (Wijayanti et al., 2021). Oleh karena itu penggunaan E-modul berbasis digital flipbook lebih menarik antusias peserta didik karena memiliki tampilan yang menarik.

Dari hasil tingkat uji keterbacaan dan analisis angket peserta didik dapat dilihat kelayakan empiris dari E-modul berbasis digital flipbook. Uji keterbacaan dilakukan dengan mengambil sampel dari E-modul yang terdiri 100 kata dalam bacaan dan dihitung suku katanya kemudian dikali 0,6. Berikut hasil rekapitulasi uji keterbacaan E-modul berbasis digital flipbook.

Tabel 4

Hasil Rekapitulasi Uji Keterbacaan E-modul Berbasis Digital Flipbook

\begin{tabular}{ccccc} 
Sampel & Halaman & $\begin{array}{c}\text { Jumlah } \\
\text { suku kata }\end{array}$ & $\begin{array}{c}\text { Jumlah } \\
\text { kalimat }\end{array}$ & level \\
\hline 1 & 1 & $\begin{array}{r}264 \times 0,6= \\
158,4\end{array}$ & 5,9 & 10 \\
& & & & \\
\hline 2 & 15 & $\begin{array}{c}267 \times 0,6= \\
160,2\end{array}$ & 5,1 & 10 \\
& & & \\
\hline 3 & 27 & $\begin{array}{c}263 \times 0,6= \\
157.8\end{array}$ & 5 & 10
\end{tabular}

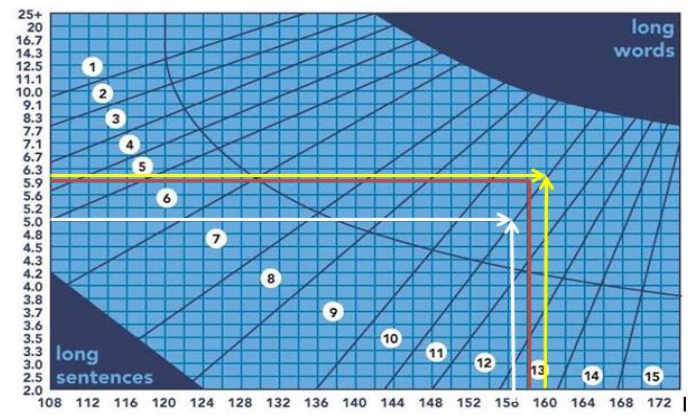

\section{Keterangan:}

Gambar 3. Hasil Uji Keterbacaan E-modul Berbasis Digital Flipbook

Garis warna merah $\quad$ : Sampel 1

Garis warna kuning : Sampel 2

Garis warna putih $\quad$ : Sampel 3

Tujuan adanya uji keterbacaan yaitu untuk mengetahui tingkat kesesuaian keterbacaan E-modul berbasis digital flipbook dengan jenjang atau tingkat pendidikan. Menurut (Fadilah, 2016) keterbacaan merupakan istilah untuk mengartikan tingkat kesulitan materi yang dibaca. Oleh karena itu E-modul yang baik harus memiliki tingkat kesulitan sesuai dengan jenjang yang ditempu. Seperti yang dikemukakan oleh 
1305 Pengembagan E-Modul Berbasis Digital Flipbook Untuk Mempermudah Pembelajaran Jarak Jauh Di SMA - Kalimatus Sa'diyah

DOI: https://doi.org/10.31004/edukatif.v3i4.561

(Amalia, 2018) bahwa buku bacaan harus sesuai dengan jenjang pendidikan peserta didik, karena akan berpengaruh terhadap keberhasilan peserta didik untuk memahami materi.

Grafik fry merupakan salah satu metode untuk menentukan hasil keterbacaan. Formula grafik fry cukup efektif digunakan untuk mengukur keterbacaan serta menentukan kelayakan bacaan untuk jenjang pendidikan (Oktaviani, I.D \& Yuliani, 2018).

Berdasarkan Tabel 2 hasil rekapitulasi uji keterbacan E-modul berbasis digital flipbook dinyatakan sesuai. Hal ini ditunjukkan pada pengambilan tiga sampel penggalan bacaan E-modul berbasis digital flipbook berada pada level 10. Angka atau level dalam grafik fry menunjukkan perkiraan tingkat keterbacaan wacana yang diukur, angka satu menunjukkan bahwa wacana yang diteliti cocok untuk pembaca level satu (kelas satu) dan seterusnya (Sari, 2017). Oleh karena itu uji keterbacaan yang dilakukan harus berada pada level 10 untuk menyatakan kesesuaian terhadap tingkat pendidikan kelas X SMA. Hal ini terbukti bahwa peserta didik mudah memahami materi yang disampaikan E-modul berbasis digital flipbook. Berikut hasil rekapitulasi angket peserta didik.

Tabel 5

Hasil Rekapitulasi Angket Peserta Didik

\begin{tabular}{|c|c|c|}
\hline Pernyataan & Nilai (\%) & Kriteria \\
\hline $\begin{array}{l}\text { E-modul berbasis digital flipbook menarik untuk } \\
\text { digunakan dalam proses pembelajaran }\end{array}$ & $81 \%$ & Sangat Layak \\
\hline $\begin{array}{l}\text { Saya kurang tertarik belajar menggunakan E-modul } \\
\text { berbasis digital flipbook. }\end{array}$ & $37 \%$ & Kurang Layak \\
\hline $\begin{array}{l}\text { Teks atau tulisan pada E-modul berbasis digital } \\
\text { flipbook mudah dibaca }\end{array}$ & $81 \%$ & Sangat Layak \\
\hline Gambar yang disajikan jelas dan tidak buram & $99 \%$ & Sangat Layak \\
\hline Gambar yang disajikan sesuai dengan materi & $99 \%$ & Sangat Layak \\
\hline $\begin{array}{l}\text { Materi dan gambar yang disajikan dalam E-modul } \\
\text { berbasis digital flipbook kurang sesuai. }\end{array}$ & $40 \%$ & Kurang Layak \\
\hline $\begin{array}{l}\text { Penyajian materi dalam E-modul berbasis digital } \\
\text { flipbook mendorong saya untuk berdiskusi dengan } \\
\text { teman-teman yang lain }\end{array}$ & $86 \%$ & Sangat Layak \\
\hline $\begin{array}{l}\text { E-modul berbasis digital flipbook menjelaskan konsep } \\
\text { materi menggunakan ilustrasi masalah yang berkaitan } \\
\text { dengan kehidupan sehari-hari }\end{array}$ & $80 \%$ & Layak \\
\hline Tanpa arahan guru saya kesulitan memahami materi. & $41 \%$ & Kurang Layak \\
\hline Saya dapat memahami materi dengan mudah & $78 \%$ & Layak \\
\hline
\end{tabular}


1306 Pengembagan E-Modul Berbasis Digital Flipbook Untuk Mempermudah Pembelajaran Jarak Jauh Di SMA - Kalimatus Sa'diyah

DOI: https://doi.org/10.31004/edukatif.v3i4.561

\begin{tabular}{|c|c|c|}
\hline Pernyataan & Nilai (\%) & Kriteria \\
\hline $\begin{array}{l}\text { Saya dapat mengikuti tahapan proses pembelajaran } \\
\text { dengan mudah }\end{array}$ & $84 \%$ & Layak \\
\hline $\begin{array}{l}\text { Saya dapat dengan mudah memahami kalimat yang } \\
\text { digunakan dalam E-modul berbasis digital flipbook }\end{array}$ & $78 \%$ & Layak \\
\hline $\begin{array}{l}\text { Saya belum memahami istilah yang digunakan dalam E- } \\
\text { modul berbasis digital flipbook. }\end{array}$ & $39 \%$ & Kurang Layak \\
\hline $\begin{array}{l}\text { Contoh soal yang digunakan dalam E-modul berbasis } \\
\text { digtal flipbook sudah sesuai dengan materi }\end{array}$ & $79 \%$ & Layak \\
\hline $\begin{array}{l}\text { Saya merasa lebih mudah belajar mengguakan E-modul } \\
\text { berbasis digital flipbook }\end{array}$ & $79 \%$ & Layak \\
\hline $\begin{array}{l}\text { Saya terterik menggunakan E-modul berbasis digital } \\
\text { flipbook untuk belajar }\end{array}$ & $80 \%$ & Layak \\
\hline $\begin{array}{l}\text { Dengan menggunakan E-modul berbasis digital } \\
\text { flipbook saya lebih tertarik belajar ekonomi }\end{array}$ & $77 \%$ & Layak \\
\hline $\begin{array}{l}\text { Saya lebih semangat belajar dengan menggunakan E- } \\
\text { modul berbasis digital flipbook }\end{array}$ & $73 \%$ & Layak \\
\hline $\begin{array}{l}\text { E-modul berbasis digital flipbook membuat saya malas } \\
\text { belajar. }\end{array}$ & $40 \%$ & Kurang Layak \\
\hline $\begin{array}{l}\text { Dengan adanya fitur-fitur dalam E-modul berbasis } \\
\text { digital flipbook dapat meningkatkan motivasi belajar } \\
\text { saya }\end{array}$ & $79 \%$ & Layak \\
\hline Rata-rata pernyataan positif & $82 \%$ & SangatLayak \\
\hline Rata-rata pernyataan negatif & $39 \%$ & Cukup Layak \\
\hline
\end{tabular}

Sumber (Zunaidah, 2016) dengan modifikasi

Angket respon peserta didik merupakan tanggapan terhadap kelayakan penggunaan dan kepraktisan yang diberikan oleh peserta didik selama kegiatan pembelajaran menggunakan E-modul berbasis digital flipbook. Setelah proses pembelajaran menggunakan E-modul berbasis digital flipbook dilakukan penyebaran angket kepada 20 peserta didik kelas X IPS SMA Negeri 14 Surabaya untuk mengetahui hasil respon dari peserta didik terkaid penggunaan E-modul berbasis digital flipbook. Hasil respon peserta didik memperoleh nilai rata-rata $82 \%$ pada pernyataan positif yang termasuk kategori sangat layak. Hal tersebut menunjukkan 
1307 Pengembagan E-Modul Berbasis Digital Flipbook Untuk Mempermudah Pembelajaran Jarak Jauh Di SMA - Kalimatus Sa'diyah

DOI: https://doi.org/10.31004/edukatif.v3i4.561

respon positif dari peserta didik terhadap E-modul berbasis digital flipbook, bahkan peserta didik ingin memiliki E-modul berbasis digital flipbook pada smartphone agar belajar lebih efisien dan efektif. Sedangkan pada pernyataan negatif memperoleh nilai rata-rata 39\% termasuk kategori kurang layak. Berdasarkan hasil respon peserta didik pada Tabel 5 menunjukkan bahwa adanya daya tarik peserta didik terhadap E-modul berbasis digital flipbook. Dapat dilihat pada pernyataan positif yang diberikan oleh peserta didik dengan nilai rata-rata $82 \%$ menandakan E-modul berbasis digital flipbook termasuk kategori sangat layak dan dapat meningkatkan motivasi belajar peserta didik serta membantu peserta didik saat proses pembelajaran berlangsung. Sedangkan pada pernyataan negatif mendapat nilai rata-rata sebesar 39\% dengan kategori kurang layak. Pada pernyataan negatif bahwa peserta didik kurang setuju terhadap pernyataan kurang tertarik menggunakan E-modul berbasis digital flipbook, materi dan gambar yang disajikan dalam E-modul berbasis digital flipbook kurang sesuai, tanpa arahan guru peserta didik kesulitan memahami materi dan istilah dalam E-modul berbasis digital flipbook, serta E-modul berbasis digital flipbook membuat peserta didik malas belajar. Hal ini diperkuat oleh penelitian (Amanullah, 2020) yang menyatakan bahwa dengan adanya E-modul berbasis digital flipbook dapat memaksimalkan pembelajaran di dalam kelas serta dapat membantu peserta didik dalam proses pembelajaran melalui media pembelajaran yang disajikan oleh guru. Kemudian penelitian (Yulaika et al., 2020) menjelaskan bahwa peserta didik mudah memahami materi yang disajikan dalam Emodul berbasis digital flipbook dengan adanya fitur-fitur pendukung didalamnya sehingga hasil belajar peserta didik mengalami peningkatan. Penelitian yang dilakukan oleh (Damarsasi, D. G., \& Saptorini, 2018) juga menjelaskan bahwa E-modul berbasis digital flipbook dapat meningkatkan hasil belajar peserta didik. Namun pada penelitian E-modul berbasis digital flipbook hanya bisa digunakan menggunakan laptop dan dengan menggunakan aplikasi flipbook maker saja. Pada penelitian pengembangan E-modul berbasis digital flipbook masih menggunakan flipbook yang gratis dan kurang efektif karena dalam penggunaannya masih kurang praktis. Sehingga perlu adanya peningkatan untuk mengakses flipbook dengan menggunakan flipbook yang berbayar yang jelas lisensinya.

\section{KESIMPULAN}

Berdasarkan penelitian pengembangan E-modul berbasis digital flipbook yang telah dikembangkan, diperoleh kesimpulan bahwa E-modul berbasis digital flipbook layak secara teoritis dengan hasil validasi sebesar 0,91 termasuk kategori valid dan layak secara empiris dengan hasil uji keterbacaan berada di level 10 yang sesuai dengan kelas 10 serta respon peserta didik mendapat nilai rata-rata sebesar $82 \%$ pada pernyataan postif termasuk kategori sangat valid dan pada pernyataan negatif mendapat nilai rata-rata $39 \%$ yang termasuk kategori kurang valid.

\section{DAFTAR PUSTAKA}

Amalia, A. \& F. H. (2018). Validasi Dan Keterbacaan Buku Ajar Berbasis Scientifik Approach Materi Perubahan Lingkungan Untuk Melatihkan Keterampilan Proses Kelas X. Jurnal BioEdu, 7(3), 545-554.

Amanullah, M. A. (2020). Pengembangan Media Pembelajaran Flipbook Digital Guna Menunjang Proses Pembelajaran di Era Revolusi Industri 4.0. Jurnal Dimensi Pendidikan Dan Pembelajaran.

Badanbahasa. (2021). Penulisan Bahasa Bacaan Literasi 2021 Dalam Rngka Gerakan Literasi Nasional. Badanbahasa.Kemdikbud.Go.Id. http://badanbahasa.kemdikbud.go.id/lamanbahasa

Balitbang. (2019). Indeks Alibaca Diluncurkan. Litbang,Kemdikbud.Go.Id. https://litbang.kemdikbud.go.id/berita-detail/31

Damarsasi, D. G., \& Saptorini, S. (2018). Pengembangan E-Modul Berbasis Flip Book Maker Materi. Jurnal Pendidikan Ilmu Sosial, 27, 1-10.

Fadilah, R. (2016). Buku Teks Bahasa Indonesia SMP dan SMA Kurikulum 2013 Terbitan Kementrian 
1308 Pengembagan E-Modul Berbasis Digital Flipbook Untuk Mempermudah Pembelajaran Jarak Jauh Di SMA - Kalimatus Sa'diyah

DOI: https://doi.org/10.31004/edukatif.v3i4.561

Pendidikan dan Kebudayaan 2014. Jurnal Pena Indonesia, 1(1), 26-49.

Hartanti, D. (2013). Media Pembelajaran (Ebook). Pendidikan Teknik Dan Arsitektur Universitas Pendidikan Indonesia.

Hayati, S. (2015). Pengembangan Media Pembelajaran Flipbook fisika untuk meningkatkan hasil belajar peserta didik. Prosiding Seminar Nasional Fisika, 4(2): 49-5.

Ilham, M., N. (2014). Pengembangan Modul Elektronik Microsoft Excel 2007 Untuk Kelas XI Sekolah Menengah Atas.

Kemdikbud. (2020a). Menuju Transformasi Digital Pendidikan Indonesia.

Pusdatin.Kemdikbud.Go.Id/Menuju-Transformasi-Digital-Pendidikan-Indonesia/.

Kemdikbud. (2020b). Sistem Informasi Kurikulum Nasional. Kurikulum.Kemdikbud.Go.Id. https://kurikulum.kemdikbud.go.id

OECD. (2019). Hasil PISA Indonesia 2018: Akses Makin Meluas, Saatnya Tingkatkan Kualitas. Kemdikbud.Go.Id. https://www.kemdikbud.go.id/main/blog/2019/hasil-pisa-indonesia-2018-akses-makin-meluas-saatnyatingkatkan-kualitas

Oktaviani, I.D \& Yuliani, Y. (2018). Validasi dan Keterbacaan Buku Ajar Berbasis Literasi Sains Pada Materi Fotosintesis Kelas XII SMA. Jurnal BioEdu, 7(2), 142-147.

Rahmawati, D., Wahyuni, S., \& Yushardi. (2017). Pengembangan Media Pembelajaran Flipbook Pada Materi Gerak Benda Di SMP. Jurnal Pembelajaran Fisika, 6(4), 326-332. https://jurnal.unej.ac.id/index.php/JPF/article/view/6213

Ratnawati, heri. (2016). Validitas Reabilitas dan Karakteristik Butir. Parama Publishing.

Riduwan. (2015). Skala Pengukuran Variabel - Variabel Penelitian. Alfabeta.

Sari, V. (2017). Tingkat Keterbacaan Buku Teks Bahasa Indonesia Jenjang Smp Menggunakan Teori Fry. Jurnal Penelitian Pendidikan Indonesia, 2(3), 1-5.

Sutarti, T. dan E. I. (2017). Kiat Sukses Meraih Hibah Penelitian Pengembangan (Mulyadi (ed.); 1st ed.). CV Budi Utama.

Thiagarajan, S. A. O. (1974). Instructional Development for Training Teachers of Exceptional Children: A Sourcebook. Indiana Univ., Bloomington. Center for Innovation in. Mc.

Wijayanti, K., Ghofur, M. A., Program, E. E., \& Surabaya, U. N. (2021). Pengembangan Media Pembelajaran E-Modul Bank Dan Sistem Pembayaran Berbasis Android Untuk Peserta Didik Kelas X. 14(1), 1-14.

Yulaika, N. F., Harti, \& Sakti, N. C. (2020). Pengembangan bahan ajar elektronik berbasis flip book untuk meningkatkan hasil belajar peserta didik. Jurnal Pendidikan Ekonomi, Manajemen Dan Keuangan, 4(1), 67-76. https://doi.org/10.26740/jpeka.v4n1.p67-76

Zunaidah, F. N. \& M. A. (2016). Kata Kunci: 2, 19-30. 